\title{
The Bidikmisi Scholarship: What Work and What Doesn't Work?
}

\section{Udik Budi Wibowo, Sudiyono, and Slamet Lestari}

Universitas Negeri Yogyakarta

\section{Abstract}

This study aims to describe the implementation of an educational scholarship program for senior high school graduated student who come from economically poor families (Bidikmisi). This scholarship spending a large amount of State budget, therefore, needs to be examined accountability of the used. Research using quantitative approach with survey method. The research found that the Bidikmisi scholarship support increased access to learning in the higher education, ensuring students retention and completion. In addition, it is also found a high learning motivation among students scholarship awardee of Bidikmisi; but nearly half of them have a low learning motivation. Subsequent management of scholarships has been running well, but not optimal. That is why, the management scholarships still need to be addressed, including financial literacy coaching to student scholarship awardee of Bidikmisi.

Keywords: Bidikmisi scholarship, higher education access, learning motivation, student retention and completion.

\section{Introduction}

article is distributed under the terms of the Creative Commons Attribution License, which permits unrestricted use and redistribution provided that the original author and source are credited.

Selection and Peer-review under the responsibility of the ICMEd Conference Committee.
To improve access to learning in the higher education and provides the opportunity to senior secondary school graduates who are not able economically, the Government provides education scholarships for high achieving students, known as BIDIKMISI, beginning in 2010. In 2017, the total budget provided to Bidikmisi is no less than Rp 4.3 trillion.[1] An undisclosed amount, which must be accounted by the Bidikmisi students, so that the State money expending is not wasted. The problem is whether the implementation of Bidikmisi program has successfully achieved the goals that have been set? For it to do research on the scholarship, with a background in program execution took Bidikmisi in Yogyakarta State University. This research is very important to describe the accountability implementation of Bidikmisi policies and programs, which can serve as a material consideration for policymakers to improve the implementation and sustainability of the scholarship policy and program. 


\section{Literature Review}

Spending money to study at higher education (HE) is seen as a good investment.[2] With humanitarian and civic missions, higher education can develop individual potential, increase knowledge, and skills to address and solve important problems that affect the social life of the community, nation and the world,[3] as well as the role as the engine of sustainable development. [4] HE has an important and strategic role in the era of globalization paradox of the 21st century, i.e. in forming and developing excellent human resources, who has the competitive and collaborative capacity, at once. So, the countries in the world, including Indonesia, seeks to continuously improve access to learning in the HE. As in 2018 and 2019, The ministry of research, technology and higher education targeted HE Gross Rate Enrollment (GRE) of 32.05\% and 32.55\%.[5] The HE GRE, actually still lags behind much of the neighbouring countries such as Singapore and Malaysia which have reached over 90\%. [6]

One of the efforts to improve the GRE in the HE is to provide educational scholarships for student awardee who come from economically poor families (Bidikmisi). The scholarships are a great help the finance of the various purposes that are directly and/or indirectly related to the needs of study at HE. In general, students need scholarships not only to pay tuition fees, but also for living expenses, rent rooms (accommodation), and the purchase of books; [7] that can reach the range of $50 \%$ to $80 \%$. [8]

Research in the United States found that the students prefer to use the loans, scholarships, and/or grants; even more than one third (35.5\%) of students use loans as primary source to pay for their tuition fee,[7] and found indications of $56 \%$ of high school graduates make a scholarship as a basis for a decision entered higher education.[9] Generally, most student loans are available for undergraduate programs, whereas scholarships are available for postgraduate programs.[10] The research found that provision of financial assistance contribute to increase HE student retention and completion,[11] or contribute to a reduction in the likelihood of delay of graduation.[12] Thus financial aid can be a strong predictor of student persistence, progression, and timely graduation, [13] as well as student success in higher education.[9]

The research results showed that student scholarship awardee can achieve a higher achievement than non-scholarship awardee or regular students.[14] In addition to influential during the education, scholarship can also carry case with impact in the work environment. The officers who came from the former awardee of scholarships in the higher education tend to has a durable retention capability in the work environment which they had choosed, have good mental health, and had many opportunities in their 
career development. [15] So, the design of financial aid to students has an impact on morale and learning motivation during study at $\mathrm{HE}$, as well as after they get a job.[16] Thus, student financial assistance should be managed effectively and efficiently, with a mechanism that is accountable, that can encourage students to complete their studies in ontime, and have the excellent competency to compete, as well as to collaborate in the work environment and life.

\section{Material \& Methodology}

\subsection{Data}

Data was generating by the questionnaire which distributed used purposive stratified cluster snowball sampling technique. Purposive refer to the Bidikmisi student scholarship awardee and regular (non-Bidikmisi) student, stratified refer to the enrollment year 2014-2017 (four years as undergraduate study time period), and cluster refers to 7 faculties at Yogyakarta State University. Unfortunately researcher difficult to get that sample student randomly, so snowball mechanism was adopted; and it could reach 130 Bidikmisi student scholarship awardee, and 100 regular students. These numbers of sample assumed adequate methodologically to ensure data constancy, then it's mean that the research finding is reliable, and could be responsible.

\subsection{Method}

This study used a survey method with a qualitative approach. The characteristic of this method is the range of the number of samples that are representative. In the study, as expressed in paragraph 3.1. above, the representativeness of the sample has not yet been fulfilled, because of the difficulty of finding student scholarship awardee of Bidikmisi spread. However with 130 samples collected data essentially still remained adequate in statistics to describe the persistent happens, and thus it is possible to generalizable to the broader sample and/or the population a number of 5,903 students.

\section{Results and Discussion}

\subsection{Result}

From the data collected now found the following result: 
TABLE 1: Bidikmisi Scholarship Benefit.

No. Benefit
$\begin{aligned} & \text { 1. } \\ & \text { Support the improvement of the } \\ & \text { learning motivation }\end{aligned}$
2. Increase access/learning
opportunities in University
3. Ensure the continuity of the study
4. Ensures timely completion of studies
Average
Category

\begin{tabular}{|c|c|c|c|c|c|}
\hline \multicolumn{6}{|c|}{ Percentage (\%) } \\
\hline & 1 & 2 & 3 & 4 & \\
\hline $\begin{array}{l}\text { Less } \\
\text { support }\end{array}$ & 2.3 & 3.1 & 40.0 & 54.6 & $\begin{array}{c}\text { Very } \\
\text { supportive }\end{array}$ \\
\hline $\begin{array}{l}\text { Very } \\
\text { little }\end{array}$ & 1.5 & 10.0 & 32.3 & 56.2 & Very much \\
\hline Less & 1.5 & 3.1 & 27.7 & 67.7 & $\begin{array}{c}\text { Totally } \\
\text { Guarantee }\end{array}$ \\
\hline \multirow[t]{3}{*}{ Less } & 3.1 & 6.2 & 40.0 & 50.8 & $\begin{array}{c}\text { Totally } \\
\text { Guarantee }\end{array}$ \\
\hline & 2.1 & 5.6 & 35 & 57.3 & \\
\hline & \multicolumn{2}{|c|}{7.7} & \multicolumn{2}{|c|}{92.3} & \\
\hline
\end{tabular}

From the table above it can be stated that in categories, $92.3 \%$ of the Bidikmisi awardee students get a lot benefit, among others, supporting an increase in the motivation to learn, improve access to learning in the university, ensuring the sustainability of the study, and ensure the timely completion of the study. There are only $7.7 \%$ of students who perceive that the Bidikmisi scholarship gives less benefits to their studies.

Further aspects of learning motivation, found the following data.

TABLE 2: The learning motivation of students scholarship awardee of Bidikmisi.

\begin{tabular}{l|l} 
No. & Indicator \\
\hline 1. & Late admission to College \\
\hline $2 . \quad$ Do not enter college without \\
permission
\end{tabular}

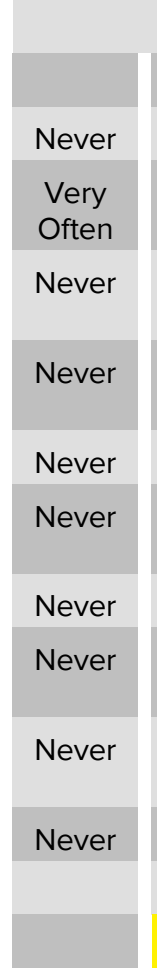

\begin{tabular}{|c|c|c|c|l|}
\hline \multicolumn{5}{|c|}{ Percentage (\%) } \\
\hline 1 & 2 & 3 & 4 & \\
\hline 27.7 & 49.2 & 19.2 & 3.8 & Very Often \\
\hline 2.3 & 3.1 & 26.9 & 67.7 & Never \\
\hline 31.5 & 61.5 & 6.2 & 0.8 & Very Often \\
\hline 9.2 & 28.5 & 53.1 & 9.2 & Very Often \\
\hline 8.5 & 33.8 & 53.1 & 4.6 & Very Often \\
\hline 11.5 & 35.4 & 40.8 & 12.3 & Very Often \\
\hline 16.9 & 53.8 & 25.4 & 3.8 & Very Often \\
\hline 21.5 & 29.2 & 39.2 & 10.1 & Very Often \\
\hline 17.7 & 25.4 & 40.0 & 16.9 & Very Often \\
\hline 2.3 & 6.9 & 28.5 & 61.5 & Very Often \\
\hline 14.9 & 32.7 & 33.2 & 19.2 & \\
\hline 47.6 & & 52.4 & \\
\hline
\end{tabular}

Based on the indicators are examined, the data above shows that in categorical there was a $52.4 \%$ Bidikmisi students who have a high learning motivation; and $47.6 \%$ 
of student Bidikmisi who has a relatively low learning motivation. However, this study into motivation paradox with benefits felt by the students as the first findings above. When further scrutiny, it seems there are about $8 \%$ to $10 \%$ students rarely access the books in the library and the National Journal (Indonesia language) as well as foreign/international journals.

As for scholarship management aspects of Bidikmisi, found the following data.

TABLE 3: Scholarship Management Bidikmisi.

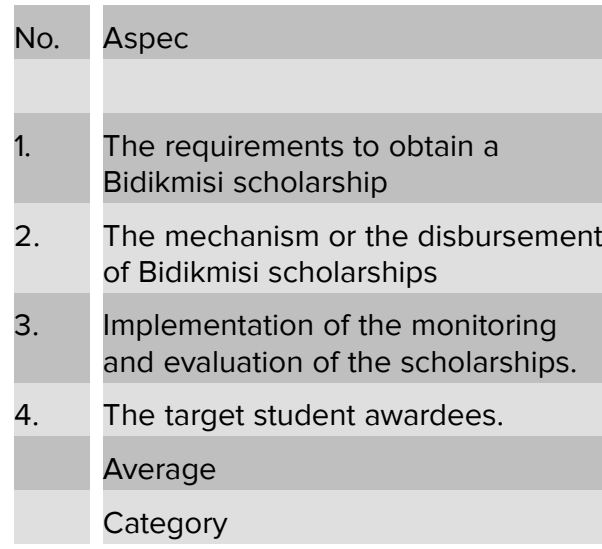

\begin{tabular}{|l|c|c|c|c|c|}
\hline & \multicolumn{5}{|c|}{ Percentage (\%) } \\
\hline Less good & 1 & 2 & 3 & 4 & \\
\hline Less good & 10.8 & 6.9 & 43.8 & 48.5 & Very Good \\
\hline Less good & 1.5 & 21.5 & 55.4 & 21.5 & Very Good \\
\hline Less Precise & 11.5 & 23.1 & 50.8 & 14.6 & Very Precise \\
\hline & 6.0 & 20.6 & 46.9 & 26.5 & \\
\hline & 26.5 & 73.5 & Very Good \\
\hline
\end{tabular}

The data above show that there are generally categorized, $73.5 \%$ of students stated that the management of Bidikmisi goes well; meanwhile, $26.5 \%$ of students stated that Bidikmisi managing less well. The management of Bidikmisi this is not good especially on aspects of delivery mechanisms or the disbursement of scholarships, the implementation of the monitoring and evaluation of the grant Bidikmisi, and target student scholarship awardee.

\subsection{Discussion}

The results of this study confirmed that scholarship can expand public access to study at higher education. The scholarship can spur a spirit of learning student awardee, ensures the study retention, and completion of the study on time. In other words, the results of these research support findings that scholarship or financial factors can increase retention and completion of study [9], and is a predictor of student success in higher education.[12] The scholarships provided for less economic capacity students, could not only respond to the purpose or promote equity of access to higher education, but they could also be used as active tools to boost students performances.[13]

With the scholarship benefits above, then it is natural when most student scholarship awardee have a high learning motivation. So, financial aid has effects on a student's motivation,[10] or student learning flourishes precisely in the synergy between teaching 
and scholarship.[17] This phenomenon also confirmed that traditional incentive in the form of financial aid could affect the learning motivation of students.[18] Although the students feel the many benefits of Bidikmisi scholarship, there are students learning motivation is still low, even their number nearly half. They rarely access the books in the library and the National Journal (Indonesia language) as well as foreign journals. It indicated that quite a number of students who rely solely on learning from lectures delivered in the classroom. In addition, it is fair to claim that students ought to be learning more give priority to obtaining good marking rather than put forward a mastery of the material more extensive and insightful coursework.

Bidikmisi management scholarship is already goes-well, in general; but not optimal. Although financial aid can increase the intake of the university, it does not mean that scholarship programs are already effective.[19] Some students moan and complain that transfer scholarships late, or not in accordance with the schedule. In addition, changes mechanism in disbursement from three monthly to per semester is quite trouble for some students, especially students who are less skilled in managing living cost, and/or students who live at rent room; so "prosperous at the beginning and the end horribly" because living cost much depleted in the early months of the acceptance period of the scholarship. Several students are also requesting the granting of scholarships Bidikmisi to be more selective, especially for supplement scholarship awardee. Student points out there are supplement Bidikmisi awardee students not comply with incapable economy requirement. Therefore, management of Bidikmisi scholarships still needs to be addressed; and the student also needs to be given training in financial literacy in order to use the scholarship effectively, efficiently and productively to support the success of their study at higher education.

\section{Conclusion}

Bidikmisi scholarship, institutionally could extend access to study at higher education, and individually-personal could encourage student learning motivation, ensure the sustainability study, and facilitate completion of studies in on time. Nevertheless, there are still Bidikmisi awardee students who has a low learning motivation and haven't been able to manage the scholarship as well. In addition, it was found that management of Bidikmisi scholarship has been running-well, but not optimal so that improvements still need to be done on an ongoing basis.

This research using a sample of the non-proportional limiting level of extent of generalization, eventhough statistically can still be accepted. Advanced research for 
it with a more representative sample needs to be done to strengthen the findings of this research. In addition, this research has yet to reach the impact or outcomes of Bidikmisi scholarship, therefore there is a chance to examine the efficiency of external and/or performance alumni scholarship awardee in this environment it works.

\section{Acknowledgement}

This research is fully supported by Annual Budget Faculty of Education Grant, Yogyakarta State University, 2018. We would like to do appreciate and thank to Isnaini Fitriana and Yuga Dwi Putra, both are students who dedicated to assisst collecting and recapitulazing the data; and thank to all students who participate in this research.

\section{References}

[1] Seftiawan, D., "Kemenristekdikti Salurkan Rp 300 Miliar Dana Beasiswa", http://www.pikiran-rakyat.com/pendidikan/2017/12/07/kemenristekdikti-salurkanrp-300-miliar-dana-beasiswa-415418. Retrieved 30 May 2018.

[2] Callender, C. \& Mason, G., "Does student loan debt deter Higher Education participation? New evidence from England", Centre for Learning and Life Chances in Knowledge Economies and Societies, http://www.llakes.ac.uk, 2017. Retrieved 30 May 2018.

[3] Stanton, T.K., "New Times Demand New Scholarship: Research Universities and Civic Engagement, Opportunities and Challenges", A Conference Report, The University of California, Los Angeles, 2007, http://www.compact.org/resources/ research/universities/, Retrieved 30 May 2018.

[4] The Commonwealth Scholarship Commission, "Evaluating Commonwealth Scholarships in the United Kingdom: Assessing impact in higher education and development." March 2012. http://cscuk.dfid.gov.uk/wp-content/uploads/2012/03/ evaluation-impact-he-report.pdf, Retrieved 17 April 2018.

[5] Kemenristekdikti, Rencana Strategis Kementerian Riset, Teknologi, dan Pendidikan Tinggi Tahun 2015 - 2019.

[6] Seftiawan, D., "Angka Partisipasi Kasar Pendidikan Tinggi Ditarget Tumbuh 2,5\%", http://www.pikiran-rakyat.com/pendidikan/2018/09/05/angka-partisipasi-kasarpendidikan-tinggi-ditarget-tumbuh-25-429777, 2018. Retrieved 6 September 2018.

[7] The Ohio State University, "National Student Financial Wellness Study: Key Findings Report", Office of Student Life, College of Education and Human Ecology, 2014, 
go.osu.edu/nsfws., Retrieved 17 April 2018.

[8] Roble, J. “Financial Barriers to College Completion”, Poverty Fact Sheet: No. 12, 2017, Institute for Research on Poverty, University of Wisconsin Madison. https://www.irp. wisc.edu/resource/ financial-barriers-to-college-completion/, Retrieved 17 April 2018.

[9] The Oregon Community Foundation, "Student Success through Scholarships Promising Practices that Support Post-Secondary Graduation", Research Brief, March, 2015. https://www.oregoncf.org/Templates/ media/files/scholarships/scholarship_research_brief.pdf. Retrieved 17 April 2018.

[10] The Commonwealth Education Hub, "Funding Education: the role of scholarships, bursaries and other mechanisms", Discussion Summary, 7 April 2016 and 29 April 2016, https://www.thecommonwealth-educationhub.net/wp-content/uploads/2016/ 04/Funding-education-the-role-of-scholarships-bursaries-and-other-mechanismdiscussion-report.pdf, Retrieved 17 April 2018.

[11] Conggres of the United State - Conggressional Budget Office. "Federal Aid for Postsecondary Students". http://www.cbo.gov/publication/53736. June 2018.

[12] Rattini, V., "The Causal Effect of Scholarships Targeted at Low Income Students on Performance: Evidence from Italy", Quaderni - Working Paper DSE N968, 2014, http://amsacta.unibo.it/4083/1/WP968.pdf. Retrieved 09 June, 2018.

[13] Ganem, N. M. \& Manasse, M., "The Relationship between Scholarships and Student Success: An Art and Design Case Study", Education Research International, Vol. May 2011, Article ID 743120, https://www.researchgate.net/publication/258380545, Retrieved 17 April 2018.

[14] Pu, Y., "Need-Based Financial Aid and Student Success in XX College in Central China", Department of Educational Research, Faculty of Education, College of Oslo, June 2013, https://www.duo.uio.no/handle/10852/37986, Retrieved 10 May 2018.

[15] Foreman, E., Perry, C. \& Wheeler, A., "Higher Education Scholarships: A review of their impact on workplace retention and career progression", Open Review of Educational Research, 2:1, 155-166, (2015), https://research-repository.griffith.edu. au/bitstream/handle/10072/99295/ForemanPUB1298.pdf?sequence=1, Retrieved 10 May 2018.

[16] Joensen, J. S. \& Mattanaz, E., "Student Aid, Academic Achievement, and Labor Market Behavior" The Institute for Evaluation of Labor Market and Education Policy (IFAU), the Swedish Ministry of Employment, December 13, 2017, https://www.ifau.se/globalassets/pdf/ se/2017/wp2017-27-student-aidacademic-achievement-and-labor-market-behavior.pdf. Retrieved 10 May 2018. 
[17] ACLS Teagle Working Group on the Teacher-Scholar, "Student Learning and Faculty Research: Connecting Teaching and Scholarship", A Teagle Foundation White Paper, American Council of Learned Societies, April 2007, http://cpr.indiana.edu/uploads/ ACLS\{\%\}20teagle5_SSB4.pdf. Retrieved 17 April, 2018.

[18] Kreber, C., "What's it really all about? The Scholarship of Teaching and Learning as an Authentic Practice", International Journal for the Scholarship of Teaching and Learning, Vol. 1, No. 1 (January 2007), http://www.georgiasouthern.edu/ijsotl. Retrieved 17 April, 2018.

[19] Judith Scott-Clayton. "The Role of Financial Aid in Promoting College Access and Success: Research Evidence and Proposals for Reform," Journal of Student Financial Aid: Vol. 45: Iss. 3, Article 3, 2015, https://publications.nasfaa.org/cgi/viewcontent. cgi?article=1586\&context=jsfa. Retrieved 17 April, 2018. 